\title{
MPOB OIL PALM (Elaeis guineensis Jacq.) GERMPLASMS LINKED TO COMPACT TRAIT FOR HIGH DENSITY PLANTING
}

\author{
NORZIHA, $A^{*}$; FADILA, A $M^{*}$; MARHALIL, $M^{*}$; ZULKIFLI, $Y^{*}$; MOHD DIN, $A^{*}$; RAJANAIDU, $\mathbf{N}^{*}$; \\ ONG-ABDULLAH, $M^{*}$ and KUSHAIRI, $A^{*}$
}

\begin{abstract}
The compact trait in oil palm was evaluated amongst the 11 germplasms collected from Nigeria, Cameroon, Zaire (now known as the Democratic Republic of Congo), Tanzania, Madagascar, Angola, Senegal, Gambia, Sierra Leone, Guinea and Ghana. The evaluation was based on the shortness of the rachis and a low height increment (HTi). However, priority was given to selection for short rachis length (RL). The MPOB-Madagascar germplasm showed the shortest $R L$ and was significantly different from other germplasms for dura $\left(R L=3.22 \mathrm{~m}, \mathrm{HTi}=0.21 \mathrm{~m} \mathrm{yr}^{-1}\right)$. As for tenera, the shortest $R L$ was found in MPOB-Tanzania germplasm $\left(R L=4.44 \mathrm{~m}, \mathrm{HTi}=0.19 \mathrm{~m} \mathrm{yr}^{-1}\right)$ but not significantly different from MPOBGuinea $\left(R L=4.49 \mathrm{~m}, \mathrm{HTi}=0.39 \mathrm{~m} \mathrm{yr}^{-1}\right)$. The coefficient of variation $(\mathrm{CV})$ for both dura and tenera accessions were considerably low with most germplasm showing CV of less than $20 \%$. The highest RL CV among duras was noted in MPOB-Madagascar germplasm (CV =18.09\%), while among teneras, high variation was observed in MPOB-Guinea germplasm $(C V=13.72 \%)$. Broad-sense heritability estimate of RL for MPOB-Madagascar was highest for dura $\left(h^{2} B=100 \%\right)$ while that for MPOB-Zaire was highest for tenera $\left(h^{2} B=100 \%\right)$. Phenotypic correlations were moderately positive between RL and HTi for most germplasms providing the possibility of developing compact palms suitable for higher density planting which consequently would result in increased oil palm yield per hectare. In summary, MPOB-Tanzania germplasm showed good potential for further introgression into advanced breeding populations for the generation of future compact planting materials.
\end{abstract}

Keywords: oil palm, compact, germplasm.

Date received: 8 January 2019; Sent for revision: 8 January 2019; Accepted: 30 September 2019; Available online: 28 August 2020.

\section{INTRODUCTION}

Oil palm (Elaeis guineensis Jacq.) is the most efficient oil bearing crop compared to other vegetable oils. With the limitation of arable land for planting, oil palm breeding is geared towards increasing yield

\footnotetext{
Malaysian Palm Oil Board,

6 Persiaran Institusi, Bandar Baru Bangi,

43000 Kajang, Selangor, Malaysia.

E-mail: norziha.abdullah@mpob.gov.my
}

per hectare of land (Phalan et al., 2016). Kushairi et al. (2018) reported that integrated pest and Ganoderma management, intensified mechanisation, advanced breeding and biotechnology as well as good agricultural practices help boost oil palm yields for both plantations and smallholdings. Oil palm germplasms that possess economically important characteristics are valuable resources for oil yield improvement. In realising this, E. guineensis germplasms were collected from Africa to broaden the genetic base of the current oil palm 
breeding materials in Malaysia. The first effort was accomplished through the collection from Nigeria in 1973 and was evaluated at MPOB Research Station at Kluang, Johor, Malaysia (Rajanaidu, 1986). Besides Nigeria, prospection was broadened to include other countries in Africa such as Angola, Cameroon, Zaire (now known as the Democratic Republic of Congo), Ghana, Guinea, Gambia, Madagascar, Sierra Leone, Senegal and Tanzania (Rajanaidu and Rao, 1987; Rajanaidu et al., 2013). Extensive screenings are continuously being carried out on these materials in order to exploit their genetic potential in oil palm breeding programmes.

Evaluation of the Nigerian germplasm highlighted several interesting attributes such as dwarfism, high iodine value (IV) and high kernel content (Rajanaidu et al., 2000). High oleic acid breeding populations were also obtained from the Nigeria germplasm (Isa et al., 2006). Whilst, the Angola palms exhibited large fruit dura (Kushairi et al., 2003) which is similar to the Deli duras. Besides that, Angola palms were found to have unique long stalks that can be used for improving harvesting efficiency (Noh et al., 2005). Angola germplasms have also exhibited wide variability in fatty acid composition (FAC) as compared to those in the existing DxP materials (Noh et al., 2002). There were palms from Nigeria and Madagascar exhibiting IV of more than 60 , which is relatively higher than the current levels $(<50)$ found in most oils (Kushairi et al., 1999). Apart from the Nigerian germplasm, high content of vitamin $\mathrm{E}$ was observed in genetic materials from Zaire, Tanzania, Angola, and Cameroon. It is obvious that this rich collection of germplasm is Malaysia's treasure trove and should be rapidly mined for potential genetic gains towards improving productivity and a sustainable future. This simultaneously provides Malaysia the competitive advantage despite the challenges faced by the industry.

One practical approach to improving oil palm yield is by increasing the number of productive oil palms per hectare. Oil palms are commercially planted with a density of 120-150 palms ha ${ }^{-1}$ (Woittiez et al., 2017). Jusoh et al. (2003) mentioned that the maximum income could be achieved from a planting density of 148 palms ha $^{-1}$, in contrast to the conventional practice of $136-148$ palms ha-1. Palat et al. (2012) stated that an effective strategy for yield maximisation is high-density planting followed by selective thinning at 8-9 years after planting. Compact palm leaves are $6.5 \mathrm{~m}$ which allow a very high density planting at 180-200 palms ha ${ }^{-1}$ compared to 7-8 m leaves of standard commercial planting (Barcelos et al., 2015).

In line with this, MPOB has developed a clone, P126 that showed rachis length (RL) at an average of $4.4 \mathrm{~m}$ which is shorter than the standard RL normally recorded for most palms at 5-6 m. This short RL is ideal for high density planting and trials of P126 planted at 198 palms ha ${ }^{-1}$ as opposed to the conventional 148 palms ha ${ }^{-1}$ have been yielding positive results (Zamzuri, 2011). In addition to being compact, P126 has been found to produce mediumsized bunches which are favourable for harvesting (Samsul et al., 2018).

Many studies on the development of compact palms have been reported. Guzman and Peralta (2010) stated that six compact clones with excellent agronomic characteristics such as short leaves and stems, precocious and high yielding have been selected for commercial production. Standard E. guineensis lines such as Deli, Ghana and Nigeria crossed with COMPACT (E. oleifera x E. guineensis) palms showed 6.6-6.9 $\mathrm{m}$ long leaves and can be planted at a density of 170 palms ha-1 which is higher than the industry standard of 136-148 palms ha $^{-1}$ (Corley and Tinker, 2003). Alvarado et al. (2010) mentioned that seeds of such hybrids are more affordable to smallholder farmers, who can get such genetic materials as a chance to boost production and make better use of scarce land resources as compared to clones.

Expansion of current plantation area to increase oil palm production is no longer a feasible option. The only alternative to increase productivity is by improving yield and profitability per hectare on existing land. Therefore, the introduction of exotic germplasm to increase genetic variability was an important strategy for the oil palm breeding programme. Based on the extensive screening of MPOB germplasm, breeding for shorter RL and lower height increment (HTi) will open up the possibility of developing compact palms which are suitable for higher density planting resulting in increased yield per hectare. The objective of this study is to screen and evaluate all MPOB oil palm (Elaeis guineensis Jacq.) germplasms with good potential for compactness with reasonable yields as breeding materials. The compact trait will be introgressed into advanced breeding populations to generate value-added commercial planting materials.

\section{MATERIALS AND METHODS}

\section{Materials}

The duras and teneras used in this evaluation were from eight breeding trials planted at the MPOB Research Station Kluang, Johor, Malaysia involving eight germplasm collections from Nigeria, Cameroon, Zaire, Tanzania, Angola, Sierra Leone, Guinea and Ghana. However, only dura palms were evaluated from three trials namely, Madagascar, Senegal and Gambia. These trials were initiated from 1976 to 2000 with various statistical designs and replications as shown in Table 1. 
TABLE 1. GERMPLASM TRIALS USED FOR COMPACT TRAIT EVALUATION

\begin{tabular}{clcccc}
\hline No. & Germplasm & Trial No. & Date planted & $\begin{array}{c}\text { Statistical } \\
\text { design }\end{array}$ & $\begin{array}{c}\text { No. of } \\
\text { replications }\end{array}$ \\
\hline 1. & Nigeria & 0.150 & Apr 1976 & 6 cubic lattice & 3 \\
2. & Cameroon & 0.218 & Nov 1986 & RCBD & 2 \\
3. & Zaire & 0.226 & Jan 1987 & RCBD & 3 \\
4. & Tanzania & 0.256 & Aug 1990 & RCBD & 4 \\
5. & Madagascar & 0.240 & Jul 1990 & CRD & 1 \\
6. & Angola & 0.311 & Apr 1994 & RCBD & 3 \\
7. & Senegal & 0.352 & Jun 1996 & ICRD & 2 \\
8. & Gambia & 0.398 & May 2000 & Progeny row & 1 \\
9. & Sierra Leone & 0.355 & Jun 1996 & RCBD & 2 \\
10. & Guinea & 0.353 & Jun 1996 & RCBD & 2 \\
11. & Ghana & 0.397 & Apr 2000 & RCBD & 4 \\
\hline
\end{tabular}

Note: RCBD - randomised complete block design.

CRD - completely randomised design.

ICRD - incomplete randomised design.

TABLE 2. OUTLINE OF ANALYSIS OF VARIANCE (ANOVA) AND VARIANCE COMPONENTS ESTIMATION

\begin{tabular}{lccc}
\hline Source & df & Mean square & EMS \\
\hline Family $(\mathrm{g})$ & $\mathrm{g}-1$ & MS1 & $\sigma^{2}{ }_{\mathrm{w}}+\mathrm{n}^{\prime} \sigma^{2}{ }_{\mathrm{g}}$ \\
Within family $(\mathrm{w})$ & $\mathrm{g}\left(\mathrm{n}^{\prime}-1\right)$ & MS2 & $\sigma^{2}{ }_{\mathrm{w}}$ \\
\hline
\end{tabular}

Note: $\mathrm{n}^{\prime}$ - harmonic mean for palms, $\mathrm{g}$ - number of family or genotype, $\mathrm{df}$ - degree of freedom and EMS - expected mean squares.

$$
\text { With: } \begin{aligned}
\sigma_{\mathrm{g}}^{2} & =\frac{\text { MS1 } 1 \text { MS2 }}{\mathrm{n}^{\prime}} \\
\sigma^{2}{ }_{\mathrm{w}} & =\text { MS2 }
\end{aligned}
$$

\section{Yield Record}

Bunch yield was recorded from 36 months after field planting onwards with two rounds per month by taking readings of bunch weight (BWT) and bunch number (BNO) of individual palms. Fresh fruit bunch (FFB) refers to the weight of bunches produced by a particular palm (BWT x BNO).

\section{Vegetative Measurement}

One complete round of vegetative measurement using the non-destructive method was carried out eight years after field planting (Corley and Breure, 1981). RL was measured from the first rudimentary leaf at the petiole to the tip of the rachis. Meanwhile, palm height was measured from ground level to the base of frond 41 . HTi is the height at year $t$ divided by $t-2$, where $t$ is the number of years after field planting.

\section{Data Analysis}

$\mathrm{RL}$ and HTi values from each trial were analysed by using analysis of variance (ANOVA), while the comparison between the germplasm means used Fisher's Least Significant Difference (LSD) at 5\% level of probability.

Heritability of RL and HTi for each germplasm collection was estimated using the ANOVA variance components method. Variance components were estimated from appropriate expectations of mean squares in Table 2. Based on the variance components data, heritability estimates are as follows:

$$
\begin{aligned}
& \text { Phenotypic variance }\left(\sigma_{\mathrm{p}}^{2}\right)=\sigma_{\mathrm{g}}^{2}+\sigma_{\mathrm{w}}^{2} \\
& \text { Heritability }\left(\mathrm{h}^{2}\right)=\frac{\sigma^{2}{ }_{\mathrm{g}}}{\sigma_{\mathrm{g}}^{2}+\sigma_{\mathrm{w}}^{2}} \times 100 \\
& \text { Heritability }\left(\mathrm{h}_{\mathrm{B}}^{2}\right)=2 \mathrm{~h}^{2}
\end{aligned}
$$

Intra-class correlation was used to estimate variance components and heritability (Falconer and Mackay, 1996). In full sib families, broad-sense heritability is the ratio of the total genetic variance to phenotypic variance is equal to $2 \mathrm{~h}^{2}$.

The relationship between RL, HTi and selected traits were determined by simple correlation using the SAS software version 9.4. Correlations between traits of interest are to determine whether selection for one trait will have an effect on another. 


\section{RESULTS AND DISCUSSION}

\section{ANOVA}

Tables 3 and 4 show mean squares for RL of duras and teneras of each collection, respectively. As for duras, the ANOVA showed highly significant difference between families in all germplasms except for Gambia. This finding indicates that significant amount of genetic variability between families exists for RL. As for teneras, there was a highly significant difference in RL between families in all collections except for Sierra Leone and Guinea. Therefore, Sierra Leone and Guinea germplasms could not be selected as the source of male parents for compact palm. The broad-sense heritability for RL of duras ranged from $19.32 \%$ (Tanzania) to $100.00 \%$ (Madagascar). The heritability estimates for RL of teneras were low to high, with the highest heritability for RL being recorded in Zaire germplasm (100.00\%).

Mean squares for HTi of duras and teneras of each collection are presented in Tables 5 and 6, respectively. The ANOVA showed highly significant difference for HTi between families in all germplasms except for Madagascar in duras. As for teneras, there were highly significant differences in HTi between families in all collections except for Guinea. The results showed that there were variations in family effects for HTi in all germplasms excluding Guinea. The broad-sense heritability for HTi of duras ranged from $28.51 \%$ (Tanzania) to $93.39 \%$ (Guinea), whilst those of teneras were medium to high, with the highest heritability for HTi being recorded in Zaire and Sierra Leone $(100.00 \%)$. This significant genetic variability suggests that selection based on HTi will produce good response if their variability could be exploited in the population (Okoye et al., 2009).

The broad-sense heritabilities of RL and HTi for both duras and teneras were high indicating good genetic control over the traits. This was expected as Breure and Corley (1983) mentioned that heritability appears high in vegetative characters. Besides that, high heritabilities were observed because the palms were derived from wild groves where the palms were highly variable. Corley and Tinker (2003) stated that the selection is likely to be more successful when the major proportion of total variation is due to genetic factors (broad-sense heritability). Therefore, it will be an advantage to select compact materials among duras in Madagascar and among teneras in Zaire germplasms.

\section{Germplasm Performance}

The frequency distribution of RL among duras and teneras, respectively is shown in Figure 1. The frequencies were close to normal distribution with mean values of $4.87 \mathrm{~m}$ for duras and $5.46 \mathrm{~m}$ for teneras. Meanwhile, Figure 2 shows the frequency distribution of HTi for duras and teneras, respectively. The frequencies were normally distributed with mean values of $0.34 \mathrm{~m} \mathrm{yr}^{-1}$ for duras and $0.40 \mathrm{~m}$ $\mathrm{yr}^{-1}$ for teneras. RL and HTi values of 11051 duras from 11 germplasms and 3372 teneras from eight germplasms involved were analysed (Tables 7 and 8). The Madagascar germplasm showed the shortest RL and was significantly different from other germplasms for dura $\left(\mathrm{RL}=3.22 \mathrm{~m}, \mathrm{HTi}=0.21 \mathrm{~m} \mathrm{yr}^{-1}\right)$. For tenera, Tanzania and Guinea germplasms showed the shortest RL compared to other germplasms. The coefficient of variation $(\mathrm{CV})$ for both dura and tenera accessions were considerably low with most germplasms showing CV less than $18 \%$ for RL. For HTi, the CV ranged from $14.49 \%$ (Madagascar) to $35.93 \%$ (Tanzania) for duras. As for teneras, the CV ranged from $13.72 \%$ (Guinea) to $35.34 \%$ (Ghana). The CV observed among the germplasms for these respective traits evaluated indicates low genetic diversity within germplasms. Okoye et al. (2018) reported that differences in CV among the populations could be described by genotype, environment, or genotype-environment interaction.

Based on scatter plots for combination of both characters (RL and HTi) (Figure 3), six germplasms (Zaire, Ghana, Cameroon, Tanzania, Guinea and Madagascar) were located below the grand mean. However, Madagascar germplasm was the most compact evaluated for duras. Figure 4 shows the scatter plots for combination of both characters. However, only those with FFB yield at more than 100 $\mathrm{kg} \mathrm{palm}^{-1} \mathrm{yr}^{-1}$ were included in the analyses. Based on the scatter plot, the Tanzania germplasm was the most compact evaluated for duras with reasonable yield. As for teneras, the compact trait was shown by Zaire, Ghana and Cameroon and the most compact trait being shown by Tanzania germplasm (Figure 5). Based on Figure 6, compact trait with good yield was shown by Tanzania germplasm.

\section{Correlations}

Simple correlation coefficients between RL and selected traits for bunch yield and vegetative characters for duras and teneras are shown in Tables 9 and 10, respectively. Correlation analysis was conducted to show how close the relationship between two variables. When such association exists, a change in the value of one trait directly affects the value of the other due to strong selection pressures in breeding (Simmonds, 1986). In general, correlation between RL and these selected traits showed the same trend as observed in both duras and teneras. RL correlated positively and significantly with FFB and average bunch weight (ABW). There were negative relationships between RL and BNO in most of the germplasms. 
TABLE 3. MEAN SQUARES, VARIANCE COMPONENTS AND HERITABILITY ESTIMATES FOR RACHIS LENGTH OF DuraS

\begin{tabular}{|c|c|c|c|c|c|c|c|c|c|c|c|c|c|c|c|c|c|c|c|c|c|c|}
\hline Source & df & NGA & df & CMR & $\mathrm{df}$ & ZAR & df & TZA & $\mathrm{df}$ & MDG & df & AGO & df & SEN & df & GAM & $\mathrm{df}$ & SLE & $\mathrm{df}$ & GUI & df & GHA \\
\hline Family & 145 & $1.8308^{* *}$ & 89 & $1.5767^{* *}$ & 55 & $0.8897^{\star *}$ & 50 & $0.9839^{* *}$ & 10 & $0.5225^{\star *}$ & 29 & $4.9892^{* *}$ & 29 & $0.6275^{* *}$ & 31 & $0.1180 \mathrm{~ns}$ & 29 & $2.9526^{* *}$ & 20 & $1.3101^{* *}$ & 49 & $5.8964^{* *}$ \\
\hline Within family & 2363 & 0.2732 & 1263 & 0.1987 & 657 & 0.1668 & 1962 & 0.1889 & 6 & 0.0357 & 710 & 0.2785 & 317 & 0.1298 & 151 & 0.1385 & 517 & 0.1805 & 369 & 0.1676 & 2388 & 0.2040 \\
\hline$\sigma_{f}^{2}$ & & 0.0908 & & 0.0918 & & 0.0570 & & 0.0202 & & 0.3284 & & 0.1913 & & 0.0551 & & - & & 0.1521 & & 0.0615 & & 0.1170 \\
\hline$\sigma^{2}{ }_{w}$ & & 0.2732 & & 0.1987 & & 0.1668 & & 0.1889 & & 0.0357 & & 0.2785 & & 0.1298 & & - & & 0.1805 & & 0.1676 & & 0.2040 \\
\hline Total & & 0.3640 & & 0.2905 & & 0.2238 & & 0.2091 & & 0.3641 & & 0.4698 & & 0.1849 & & - & & 0.3326 & & 0.2291 & & 0.3210 \\
\hline Heritability $\left(\mathrm{h}_{\mathrm{B}}^{2}\right)$ & & $49.89 \%$ & & $63.20 \%$ & & $50.94 \%$ & & $19.32 \%$ & & $100.00 \%$ & & $81.44 \%$ & & $59.60 \%$ & & - & & $91.46 \%$ & & $53.69 \%$ & & $72.90 \%$ \\
\hline
\end{tabular}

Note: ** Significant at $\mathrm{P} \leq 0.01$, otherwise non-significant (ns).

NGA - Nigeria, CMR - Cameroon, ZAR - Zaire, TZA - Tanzania, MDG - Madagascar, AGO - Angola, SEN - Senegal, GAM - Gambia, SLE - Sierra Leone, GUI - Guinea, GHA - Ghana.

df - degree of freedom.

TABLE 4. MEAN SQUARES, VARIANCE COMPONENTS AND HERITABILITY ESTIMATES FOR RACHIS LENGTH OF Teneras

\begin{tabular}{|c|c|c|c|c|c|c|c|c|c|c|c|c|c|c|c|c|}
\hline Source & df & NGA & df & CMR & $\mathrm{df}$ & ZAR & $\mathrm{df}$ & TZA & df & AGO & $\mathrm{df}$ & SLE & $\mathrm{df}$ & GUI & df & GHA \\
\hline Family & 145 & $1.3512^{* *}$ & 57 & $1.0680^{* *}$ & 12 & $0.9898^{* *}$ & 50 & $0.3473^{* *}$ & 24 & $1.3825^{\star *}$ & 10 & $0.5691 \mathrm{~ns}$ & 10 & $0.5589 \mathrm{~ns}$ & 35 & $0.6211^{* *}$ \\
\hline Within family & 1889 & 0.2408 & 266 & 0.1989 & 32 & 0.2162 & 515 & 0.1881 & 160 & 0.2859 & 15 & 0.3174 & 9 & 0.1812 & 131 & 0.2392 \\
\hline$\sigma_{f}^{2}$ & & 0.0798 & & 0.1583 & & 0.2566 & & 0.0146 & & 0.1501 & & - & & - & & 0.0859 \\
\hline$\sigma_{w}^{2}$ & & 0.2408 & & 0.1898 & & 0.2162 & & 0.1881 & & 0.2859 & & - & & - & & 0.2392 \\
\hline Total & & 0.3206 & & 0.3481 & & 0.4728 & & 0.2027 & & 0.4360 & & - & & - & & 0.3251 \\
\hline Heritability $\left(\mathrm{h}_{\mathrm{B}}^{2}\right)$ & & $49.78 \%$ & & $90.95 \%$ & & $100.00 \%$ & & $14.41 \%$ & & $68.85 \%$ & & - & & - & & $52.85 \%$ \\
\hline
\end{tabular}

Note: ** Significant at $\mathrm{P} \leq 0.01$, otherwise non-significant (ns).

NGA - Nigeria, CMR - Cameroon, ZAR - Zaire, TZA - Tanzania, AGO - Angola, SLE - Sierra Leone, GUI - Guinea,

GHA - Ghana.

$\mathrm{df}$ - degree of freedom.

TABLE 5. MEAN SQUARES, VARIANCE COMPONENTS AND HERITABILITY ESTIMATES FOR HEIGHT INCREMENT OF Duras

\begin{tabular}{|c|c|c|c|c|c|c|c|c|c|c|c|c|c|c|c|c|c|c|c|c|c|c|}
\hline Source & df & NGA & df & CMR & df & ZAR & df & TZA & df & MDG & df & AGO & df & SEN & df & GAM & df & SLE & $\mathrm{df}$ & GUI & df & GHA \\
\hline Family & 145 & $5.4049^{* *}$ & 89 & $0.8855^{* *}$ & 55 & $0.5857^{\star *}$ & 50 & $1.1100^{* *}$ & 10 & $0.0444 \mathrm{~ns}$ & 29 & $2.7946^{* *}$ & 29 & $1.2722^{* *}$ & 31 & $0.8180^{\star *}$ & 29 & $2.8248^{* *}$ & 20 & $3.3127^{* *}$ & 49 & $3.1195^{\star *}$ \\
\hline Within $\mathrm{f}$ & 2363 & 0.5115 & 1263 & 0.1304 & 657 & 0.1104 & 1962 & 0.1471 & 6 & 0.0166 & 710 & 0.3108 & 317 & 0.2867 & 151 & 0.2346 & 517 & 0.3502 & 369 & 0.1919 & 2388 & 0.2154 \\
\hline$\sigma_{f}^{2}$ & & 0.28381 & & 0.05028 & & 0.03749 & & 0.02446 & & - & & 0.10086 & & 0.10945 & & 0.10286 & & 0.13578 & & 0.16811 & & 0.05969 \\
\hline$\sigma_{w}^{2}$ & & 0.51151 & & 0.13041 & & 0.11039 & & 0.14713 & & - & & 0.31080 & & 0.28665 & & 0.23459 & & 0.35019 & & 0.19189 & & 0.21538 \\
\hline Total & & 0.79532 & & 0.18069 & & 0.14788 & & 0.17159 & & - & & 0.41166 & & 0.39610 & & 0.33745 & & 0.48597 & & 0.36000 & & 0.27507 \\
\hline Heritability $\left(\mathrm{h}_{\mathrm{B}}^{2}\right)$ & & $71.37 \%$ & & $55.65 \%$ & & $50.70 \%$ & & $28.51 \%$ & & - & & $49.00 \%$ & & $55.26 \%$ & & $60.96 \%$ & & $55.88 \%$ & & $93.39 \%$ & & $43.40 \%$ \\
\hline
\end{tabular}

Note: ** Significant at $\mathrm{P} \leq 0.01$, otherwise non-significant (ns).

NGA - Nigeria, CMR - Cameroon, ZAR - Zaire, TZA - Tanzania, MDG - Madagascar, AGO - Angola, SEN - Senegal, GAM - Gambia

SLE - Sierra Leone, GUI - Guinea, GHA - Ghana. df - degree of freedom. 
TABLE 6. MEAN SQUARE, VARIANCE COMPONENTS AND HERITABILITY ESTIMATES FOR HEIGHT INCREMENT OF Teneras

\begin{tabular}{|c|c|c|c|c|c|c|c|c|c|c|c|c|c|c|c|c|}
\hline Source & $\mathrm{df}$ & NGA & df & CMR & $\mathrm{df}$ & ZAR & df & TZA & df & AGO & $\mathrm{df}$ & SLE & $\mathrm{df}$ & GUI & df & GHA \\
\hline Family & 145 & $4.8423^{\star *}$ & 57 & $0.2902^{* *}$ & 12 & $0.4059^{* *}$ & 50 & $0.3585^{\star *}$ & 24 & $1.4995^{* *}$ & 10 & $1.1294^{* *}$ & 10 & $0.4815 \mathrm{~ns}$ & 35 & $0.5870^{\text {** }}$ \\
\hline Within family & 1889 & 0.4819 & 266 & 0.0958 & 32 & 0.0672 & 515 & 0.1103 & 160 & 0.2450 & 15 & 0.2788 & 9 & 0.1786 & 131 & 0.2223 \\
\hline$\sigma_{f}^{2}$ & & 0.31326 & & 0.03504 & & 0.11238 & & 0.02269 & & 0.17171 & & 0.37742 & & - & & 0.08201 \\
\hline$\sigma^{2}{ }_{w}$ & & 0.48193 & & 0.09581 & & 0.06715 & & 0.11034 & & 0.24501 & & 0.27880 & & - & & 0.22234 \\
\hline Total & & 0.79519 & & 0.13085 & & 0.17953 & & 0.13303 & & 0.41672 & & 0.65622 & & - & & 0.30435 \\
\hline Heritability $\left(\mathrm{h}_{\mathrm{B}}^{2}\right)$ & & $78.79 \%$ & & $53.56 \%$ & & $100.00 \%$ & & $34.11 \%$ & & $82.41 \%$ & & $100.00 \%$ & & - & & $53.89 \%$ \\
\hline
\end{tabular}

Note: ** Significant at $\mathrm{P} \leq 0.01$, otherwise non-significant.

NGA - Nigeria, CMR - Cameroon, ZAR - Zaire, TZA - Tanzania, AGO - Angola, SLE - Sierra Leone, GUI - Guinea

GHA - Ghana. df - degree of freedom.

TABLE 7. EVALUATION OF COMPACTNESS AMONG Duras IN THE MPOB GERMPLASM

\begin{tabular}{|c|c|c|c|c|c|c|c|c|c|c|c|c|}
\hline \multirow[b]{2}{*}{ No. } & \multirow[b]{2}{*}{ Germplasm } & \multirow[b]{2}{*}{$\mathbf{N}$} & \multicolumn{2}{|c|}{ Rachis length (m) } & \multicolumn{2}{|c|}{$\begin{array}{l}\text { Height increment } \\
\qquad\left(\mathrm{m} \mathrm{yr}^{-1}\right)\end{array}$} & \multicolumn{3}{|c|}{ Yield performance } & \multicolumn{3}{|c|}{ Bunch analysis } \\
\hline & & & Mean & $\begin{array}{l}\text { Coeff. of } \\
\text { variation } \\
\text { (CV) }\end{array}$ & Mean & $\begin{array}{l}\text { Coeff. of } \\
\text { variation } \\
\text { (CV) }\end{array}$ & $\begin{array}{c}\text { Fresh fruit } \\
\text { bunch } \\
\left(\mathrm{kg} \mathrm{palm}^{-1} \mathrm{yr}^{-1}\right)\end{array}$ & $\begin{array}{l}\text { Bunch number } \\
\text { (No.) }\end{array}$ & $\begin{array}{c}\text { Average } \\
\text { bunch weight } \\
\left(\mathrm{kg} \mathrm{palm}^{-1} \mathrm{yr}^{-1}\right)\end{array}$ & $\begin{array}{c}\text { Mesocarp } \\
\text { to fruit } \\
(\%)\end{array}$ & $\begin{array}{l}\text { Oil to bunch } \\
(\%)\end{array}$ & $\begin{array}{l}\text { Oil yield } \\
\text { (kg) }\end{array}$ \\
\hline 1. & Nigeria & 2507 & $5.92^{\mathrm{a}}$ & 10.19 & $0.40^{\mathrm{b}}$ & 22.45 & $153.74^{\mathrm{a}}$ & $12.85^{\mathrm{f}}$ & $12.60^{b}$ & $48.21^{\mathrm{b}}$ & $15.89^{\mathrm{a}}$ & $24.26^{\mathrm{a}}$ \\
\hline 2. & Cameroon & 1334 & $4.62^{c}$ & 11.56 & $0.27^{\mathrm{d}}$ & 25.37 & $91.83^{\text {ef }}$ & $14.02^{\mathrm{d}}$ & $6.77^{\mathrm{e}}$ & $42.24^{\text {cd }}$ & $11.95^{\mathrm{de}}$ & $11.15^{\mathrm{e}}$ \\
\hline 3. & Zaire & 709 & $4.73^{c}$ & 9.93 & $0.25^{\mathrm{e}}$ & 25.43 & $92.21^{\text {def }}$ & $12.92^{\text {ef }}$ & $7.44^{\mathrm{d}}$ & $48.80^{\mathrm{ab}}$ & $15.05^{\mathrm{b}}$ & $14.47^{\mathrm{c}}$ \\
\hline 4. & Tanzania & 2013 & $4.41^{\mathrm{d}}$ & 10.37 & $0.19^{\mathrm{f}}$ & 35.93 & $124.04^{\mathrm{b}}$ & $13.33^{\text {def }}$ & $9.45^{\mathrm{c}}$ & $47.65^{\mathrm{b}}$ & $13.92^{c}$ & $16.74^{\mathrm{b}}$ \\
\hline 5. & Madagascar & 17 & $3.22^{\mathrm{i}}$ & 18.09 & $0.21^{\mathrm{f}}$ & 14.49 & $14.01^{\mathrm{h}}$ & $5.19^{\mathrm{g}}$ & $2.78^{g}$ & $36.82^{\text {ef }}$ & $8.47^{g}$ & $1.29^{\mathrm{h}}$ \\
\hline 6. & Angola & 733 & $5.56^{\mathrm{b}}$ & 12.21 & $0.45^{\mathrm{a}}$ & 23.63 & $159.73^{\mathrm{a}}$ & $12.40^{\mathrm{f}}$ & $13.34^{\mathrm{a}}$ & $50.20^{\mathrm{a}}$ & $15.66^{\mathrm{ab}}$ & $24.97^{\mathrm{a}}$ \\
\hline 7. & Senegal & 359 & $3.87^{g}$ & 11.41 & $0.47^{\mathrm{a}}$ & 22.30 & $100.11^{\mathrm{d}}$ & $20.01^{b}$ & $5.04^{\mathrm{f}}$ & $34.77^{g}$ & $8.37^{8}$ & $6.64^{g}$ \\
\hline 8. & Gambia & 183 & $3.52^{\mathrm{h}}$ & 10.44 & $0.46^{\mathrm{a}}$ & 20.89 & $66.17^{g}$ & $21.30^{\mathrm{a}}$ & $3.12^{\mathrm{g}}$ & $38.11^{\mathrm{e}}$ & $11.14^{\mathrm{f}}$ & $7.60^{\mathrm{g}}$ \\
\hline 9. & Sierra Leone & 547 & $4.15^{\mathrm{e}}$ & 13.81 & $0.45^{\mathrm{a}}$ & 25.61 & $115.09^{c}$ & $17.39^{c}$ & $6.77^{\mathrm{e}}$ & $35.82 \mathrm{f}^{g}$ & $10.61^{\mathrm{f}}$ & $10.03^{\mathrm{ef}}$ \\
\hline 10. & Guinea & 390 & $4.00^{\mathrm{f}}$ & 11.90 & $0.34^{c}$ & 29.34 & $98.20^{\mathrm{de}}$ & $13.00^{\text {def }}$ & $7.69^{\mathrm{d}}$ & $43.96^{\mathrm{c}}$ & $12.06^{\mathrm{d}}$ & $12.74^{\mathrm{d}}$ \\
\hline 11. & Ghana & 2259 & $4.69^{c}$ & 11.80 & $0.27^{\mathrm{de}}$ & 31.83 & $87.87^{\mathrm{f}}$ & $13.89^{\mathrm{de}}$ & $6.60^{\mathrm{e}}$ & $41.77^{\mathrm{d}}$ & $11.21^{\mathrm{ef}}$ & $9.23^{\mathrm{f}}$ \\
\hline \multirow[t]{3}{*}{12.} & Advanced Dura & 382 & 5.50 & 11.19 & 0.40 & 32.65 & 103.38 & 7.88 & 13.23 & 59.14 & 16.80 & 17.48 \\
\hline & Mean & 11051 & 4.87 & 11.17 & 0.34 & 27.19 & & & & & & \\
\hline & LSD & & 0.13 & & 0.02 & & & & & & & \\
\hline
\end{tabular}

Note: Means with the same letter are not significantly different at $\mathrm{p} \leq 0.05$ based on Least Significant Difference (LSD).

Figures in bold within the mean column are minimum and maximum values. 
TABLE 8. EVALUATION OF COMPACTNESS AMONG Teneras IN THE MPOB GERMPLASM

\begin{tabular}{|c|c|c|c|c|c|c|c|c|c|c|c|c|}
\hline \multirow[b]{2}{*}{ No. } & \multirow[b]{2}{*}{ Germplasm } & \multirow[b]{2}{*}{$\mathbf{N}$} & \multicolumn{2}{|c|}{ Rachis length (m) } & \multicolumn{2}{|c|}{$\begin{array}{l}\text { Height increment } \\
\qquad\left(\mathrm{m} \mathrm{yr}^{-1}\right)\end{array}$} & \multicolumn{3}{|c|}{ Yield performance } & \multicolumn{3}{|c|}{ Bunch analysis } \\
\hline & & & Mean & $\begin{array}{l}\text { Coeff. of } \\
\text { variation } \\
\text { (CV) }\end{array}$ & Mean & $\begin{array}{l}\text { Coeff. of } \\
\text { variation } \\
\text { (CV) }\end{array}$ & $\begin{array}{l}\text { Fresh fruit } \\
\text { bunch } \\
\left(\mathrm{kg} \mathrm{palm}^{-1} \mathrm{yr}^{-1}\right)\end{array}$ & $\begin{array}{l}\text { Bunch } \\
\text { number } \\
\text { (No.) }\end{array}$ & $\begin{array}{c}\text { Average bunch } \\
\text { weight } \\
\left(\mathrm{kg} \mathrm{palm}^{-1} \mathrm{yr}^{-1}\right)\end{array}$ & $\begin{array}{c}\text { Mesocarp } \\
\text { to fruit } \\
(\%)\end{array}$ & $\begin{array}{l}\text { Oil to bunch } \\
(\%)\end{array}$ & $\begin{array}{l}\text { Oil yield } \\
(\mathbf{k g})\end{array}$ \\
\hline 1. & Nigeria & 2035 & $5.90^{\mathrm{a}}$ & 9.58 & $0.40^{\mathrm{b}}$ & 22.42 & $161.98^{b}$ & $14.72^{\mathrm{b}}$ & $11.49^{\mathrm{b}}$ & $75.04^{a}$ & $22.69^{a}$ & $36.46^{a}$ \\
\hline 2. & Cameroon & 324 & $4.80^{c}$ & 12.24 & $0.26^{c}$ & 22.90 & $101.59^{d}$ & $14.81^{\mathrm{b}}$ & $7.18^{\mathrm{f}}$ & $66.27^{\mathrm{d}}$ & $17.76^{\mathrm{d}}$ & $17.90^{\mathrm{e}}$ \\
\hline 3. & Zaire & 45 & $5.03^{\mathrm{b}}$ & 13.00 & $0.24^{c}$ & 27.78 & $91.10^{\mathrm{d}}$ & $10.67^{e}$ & $8.53^{\mathrm{e}}$ & $72.04^{\mathrm{bc}}$ & $22.40^{\mathrm{a}}$ & $21.32^{\mathrm{d}}$ \\
\hline 4. & Tanzania & 566 & $4.44^{\mathrm{d}}$ & 10.14 & $0.19^{d}$ & 32.07 & $130.89^{c}$ & $12.89^{\mathrm{cd}}$ & $10.38^{\mathrm{cd}}$ & $70.25^{c}$ & $19.66^{\mathrm{bc}}$ & $25.32^{c}$ \\
\hline 5. & Angola & 189 & $5.75^{\mathrm{a}}$ & 11.48 & $0.45^{\mathrm{a}}$ & 24.69 & $161.23^{b}$ & $12.52^{\mathrm{d}}$ & $13.22^{\mathrm{a}}$ & $73.76^{\mathrm{ab}}$ & $22.50^{\mathrm{a}}$ & $37.28^{\mathrm{a}}$ \\
\hline 6. & Sierra Leone & 26 & $4.74^{c}$ & 13.66 & $0.40^{\mathrm{b}}$ & 32.57 & $193.16^{\mathrm{a}}$ & $18.17^{a}$ & $11.01^{\mathrm{bc}}$ & $75.08^{\mathrm{a}}$ & $19.31^{\mathrm{bc}}$ & $31.92^{\mathrm{b}}$ \\
\hline 7. & Guinea & 20 & $4.49^{\mathrm{d}}$ & 13.72 & $0.39^{\mathrm{b}}$ & 13.72 & $139.92^{c}$ & $14.18^{\mathrm{bc}}$ & $9.98^{\mathrm{d}}$ & $75.57^{a}$ & $20.45^{\mathrm{b}}$ & $32.98^{\mathrm{b}}$ \\
\hline 8. & Ghana & 167 & $4.90^{\mathrm{bc}}$ & 11.54 & $0.26^{c}$ & 35.34 & $95.28^{\mathrm{d}}$ & $12.48^{\mathrm{d}}$ & $7.86^{\mathrm{ef}}$ & $70.28^{c}$ & $18.95^{\mathrm{cd}}$ & $16.54^{\mathrm{e}}$ \\
\hline \multirow[t]{3}{*}{9.} & Standard cross & 19 & 5.04 & 9.87 & 0.49 & 21.17 & 174.75 & 12.31 & 14.33 & 82.85 & 22.15 & 41.67 \\
\hline & Mean & 3372 & 5.46 & 10.21 & 0.40 & 24.87 & & & & & & \\
\hline & LSD & & 0.20 & & 0.03 & & & & & & & \\
\hline
\end{tabular}

Note: Means with the same letter are not significantly different at $\mathrm{p} \leq 0.05$ based on Least Significant Difference (LSD).

Figures in bold within the mean column are minimum and maximum values.

TABLE 9. PHENOTYPIC CORRELATION OF RACHIS LENGTH TO BUNCH YIELD AND VEGETATIVE CHARACTERS OF DUra

\begin{tabular}{|c|c|c|c|c|c|c|c|c|c|c|c|}
\hline & FFB & BNO & ABW & BI & FP & PCS & LL & LW & LN & HT & DIA \\
\hline RL-NGA & $0.17^{* \star}$ & $-0.16^{* \star}$ & $0.31^{* *}$ & $-0.22^{* *}$ & $-0.20^{* *}$ & $0.63^{* *}$ & $0.33^{* *}$ & $0.52^{* *}$ & $0.49^{* *}$ & $0.25^{\star \star}$ & $0.19^{* *}$ \\
\hline RLCMR & $0.36^{* \star}$ & $0.05 \mathrm{~ns}$ & $0.42^{* \star}$ & $-0.01 \mathrm{~ns}$ & $-0.23^{* *}$ & $0.52^{\star *}$ & $0.52^{* *}$ & $0.38^{* *}$ & $0.47^{\star *}$ & $0.26^{\star \star}$ & $0.22^{* *}$ \\
\hline RL-ZRE & $0.15^{* *}$ & $-0.13^{\star *}$ & $0.39^{* *}$ & $-0.20^{* *}$ & $-0.17^{\star *}$ & $0.49^{* *}$ & $0.37^{\star *}$ & $0.50^{* *}$ & $0.25^{\star *}$ & $0.29^{* \star}$ & $0.27^{* *}$ \\
\hline RL-TZA & $0.39^{* *}$ & $0.15^{* *}$ & $0.39^{* *}$ & $0.22^{* *}$ & $0.04 \mathrm{~ns}$ & $0.38^{\star \star}$ & $0.26^{* *}$ & $0.22^{* *}$ & $0.47^{\star \star}$ & $0.36^{\star \star}$ & $0.12^{* *}$ \\
\hline RL-MDG & $0.36 \mathrm{~ns}$ & $0.37 \mathrm{~ns}$ & $-0.41 \mathrm{~ns}$ & $0.26 \mathrm{~ns}$ & $0.60^{*}$ & $0.42 \mathrm{~ns}$ & $0.60^{*}$ & $0.34 \mathrm{~ns}$ & $0.75^{* *}$ & $0.33 \mathrm{~ns}$ & $0.20 \mathrm{~ns}$ \\
\hline RL-AGO & $0.28^{* *}$ & $-0.25^{* *}$ & $0.46^{* *}$ & $-0.15^{* *}$ & $-0.39^{* *}$ & $0.61^{* *}$ & $0.43^{* *}$ & $0.37^{* *}$ & $0.55^{* *}$ & $0.10 \mathrm{~ns}$ & $0.26^{* *}$ \\
\hline RL-SEN & $0.18^{* *}$ & $-0.07 \mathrm{~ns}$ & $0.34^{* *}$ & $-0.08 \mathrm{~ns}$ & $-0.24^{* *}$ & $0.60^{* *}$ & $0.47^{\star *}$ & $0.18^{* *}$ & $0.34^{* *}$ & $-0.06 \mathrm{~ns}$ & $0.23^{* *}$ \\
\hline RL-GAM & $0.15^{\star}$ & $-0.01 \mathrm{~ns}$ & $0.31^{* *}$ & $-0.02 \mathrm{~ns}$ & $-0.23^{* *}$ & $0.50^{* *}$ & $0.15^{\star}$ & $0.26^{* *}$ & $0.30^{* *}$ & $0.05 \mathrm{~ns}$ & $0.28^{* *}$ \\
\hline RL-SLE & $0.62^{* *}$ & $0.20^{* *}$ & $0.56^{* *}$ & $0.28^{* *}$ & $-0.43^{* *}$ & $0.75^{* *}$ & $0.48^{* *}$ & $0.47^{* *}$ & $0.63^{* *}$ & $0.19^{* *}$ & $0.18^{* *}$ \\
\hline RL-GUI & $0.37^{\star *}$ & $-0.03 n s$ & $0.50^{* *}$ & $0.13^{*}$ & $-0.37^{* *}$ & $0.59^{* *}$ & $0.45^{\star *}$ & $0.35^{* *}$ & $0.40^{* *}$ & $0.17^{\star *}$ & $0.19^{* *}$ \\
\hline RL-GHA & $0.27^{\star *}$ & $-0.16^{\star *}$ & $0.48^{\star \star}$ & $-0.03 \mathrm{~ns}$ & $-0.48^{\star *}$ & $0.70^{\star *}$ & $0.40^{* *}$ & $0.46^{* *}$ & $0.50^{* *}$ & $0.17^{\star *}$ & $0.10^{* *}$ \\
\hline
\end{tabular}

Note: * ** Significant at $\mathrm{P} \leq 0.05$ and $\mathrm{P} \leq 0.01$, respectively. Otherwise, non-significant (ns).

FFB - fresh fruit bunch, BNO - bunch number, ABW - average bunch weight, BI - bunch index, FP - frond production, PCS - petiole cross-section, LL - leaflet length, LW - leaflet width, LN - leaflet number, HT - palm height, DIA - trunk diameter. 
TABLE 10. PHENOTYPIC CORRELATION OF RACHIS LENGTH TO BUNCH YIELD AND VEGETATIVE CHARACTERS OF Tenera

\begin{tabular}{lccccccccccccccccc}
\hline & FFB & BNO & ABW & BI & FP & PCS & LL & LW & LN & HT & DIA \\
\hline RL-NGA & $0.18^{* *}$ & $-0.12^{* *}$ & $0.27^{* *}$ & $-0.17^{* *}$ & $0.18^{* *}$ & $0.60^{* *}$ & $0.39^{* *}$ & $0.35^{* *}$ & $0.51^{* *}$ & $0.02 \mathrm{~ns}$ & $0.13^{* *}$ \\
RL-CMR & $0.42^{* *}$ & $-0.10 \mathrm{~ns}$ & $0.58^{* *}$ & $0.04 \mathrm{~ns}$ & $-0.42 \mathrm{~ns}$ & $0.65^{* *}$ & $0.58^{* *}$ & $0.50^{* *}$ & $0.56^{* *}$ & $0.24^{* *}$ & $0.18^{*}$ \\
RL-ZRE & $0.59^{* *}$ & $0.19 \mathrm{~ns}$ & $0.71^{* *}$ & $0.15 \mathrm{~ns}$ & $-0.29 \mathrm{~ns}$ & $0.88^{* *}$ & $0.58^{* *}$ & $0.84^{* *}$ & $0.70^{* *}$ & $0.30^{*}$ & $0.28 \mathrm{~ns}$ \\
RL-TZA & $0.44^{* *}$ & $0.21^{* *}$ & $0.39^{* *}$ & $0.28^{* *}$ & $0.002 \mathrm{~ns}$ & $0.41^{* *}$ & $0.28^{* *}$ & $0.23^{* *}$ & $0.62^{* *}$ & $0.36^{* *}$ & $0.15^{* *}$ \\
RL-AGO & $0.32^{* *}$ & $-0.10 \mathrm{~ns}$ & $0.34^{* *}$ & $-0.10 \mathrm{~ns}$ & $-0.37^{* *}$ & $0.62^{* *}$ & $0.42^{* *}$ & $0.38^{* *}$ & $0.44^{* *}$ & $0.27^{* *}$ & $0.12 \mathrm{~ns}$ \\
RL-SLE & $0.40^{*}$ & $-0.23 \mathrm{~ns}$ & $0.58^{* *}$ & $0.40^{*}$ & $-0.53^{* *}$ & $0.30 \mathrm{~ns}$ & $0.25 \mathrm{~ns}$ & $0.22 \mathrm{~ns}$ & $0.55^{* *}$ & $-0.10 \mathrm{~ns}$ & $-0.24 \mathrm{~ns}$ \\
RL-GUI & $0.44 \mathrm{~ns}$ & $0.11 \mathrm{~ns}$ & $0.58^{* *}$ & $0.14 \mathrm{~ns}$ & $0.03 \mathrm{~ns}$ & $0.69^{* *}$ & $0.13 \mathrm{~ns}$ & $0.21 \mathrm{~ns}$ & $0.84^{* *}$ & $0.65^{* *}$ & $0.18 \mathrm{~ns}$ \\
RL-GHA & $0.20^{*}$ & $-0.26^{* *}$ & $0.49^{* *}$ & $-0.12 \mathrm{~ns}$ & $-0.48^{* *}$ & $0.70^{* *}$ & $0.31^{* *}$ & $0.62^{* *}$ & $0.65^{* *}$ & $0.39^{* *}$ & $0.14 \mathrm{~ns}$ \\
\hline
\end{tabular}

Note: * ** Significant at $\mathrm{P} \leq 0.05$ and $\mathrm{P} \leq 0.01$, respectively. Otherwise, non-significant (ns).

FFB - fresh fruit bunch, BNO - bunch number, ABW - average bunch weight, BI - bunch index, FP - frond production, PCS - petiole, cross-section, LL - leaflet length, LW - leaflet width, LN - leaflet number, HT - palm height, DIA - trunk diameter.

(a)

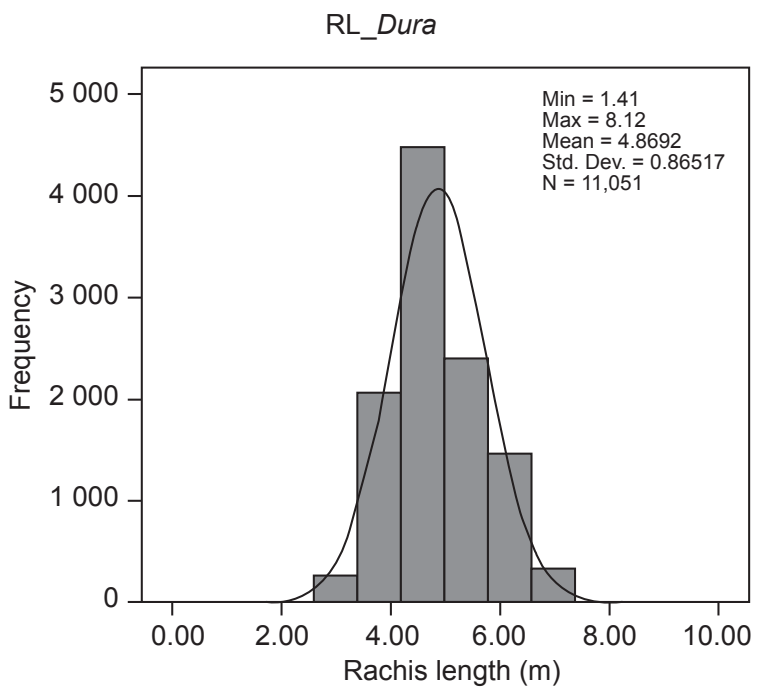

(b)

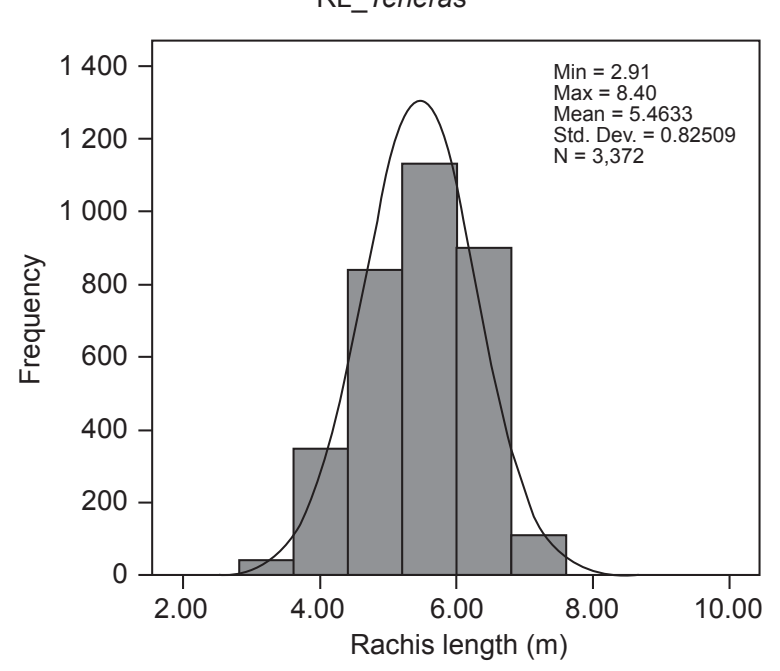

Figure 1. Frequency distribution of rachis length $(R L)$ among duras (a) and teneras $(b)$ in MPOB germplasms.

(a)

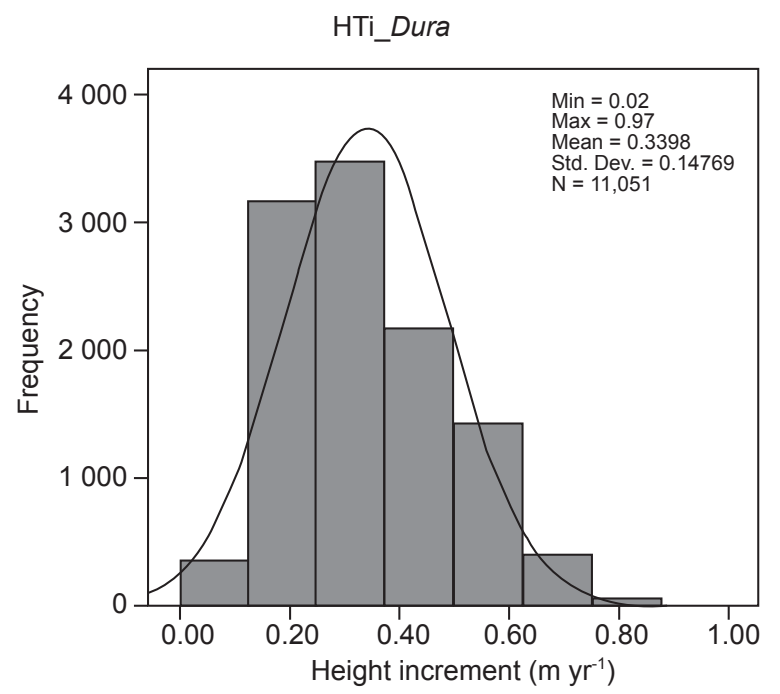

(b)

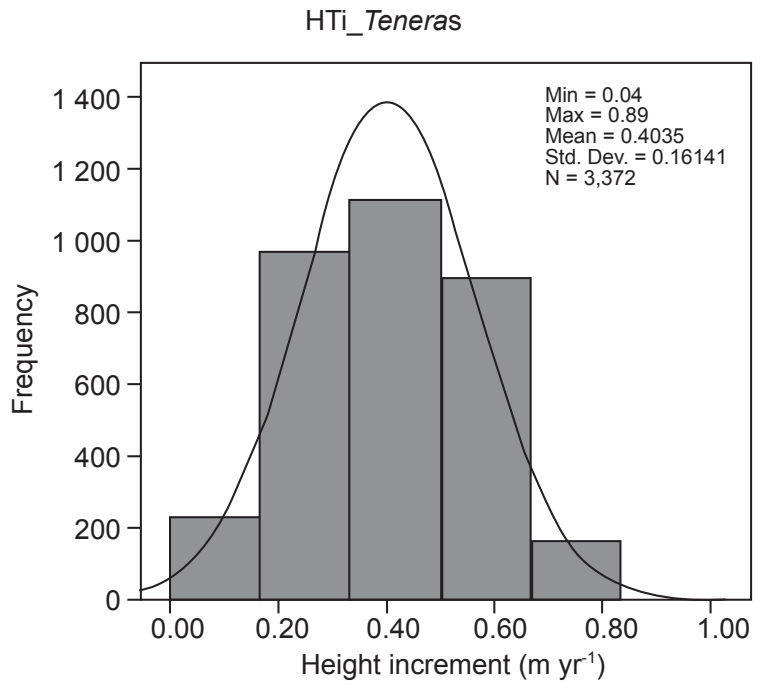

Figure 2. Frequency distribution of height increment (HTi) among duras (a) and teneras (b) in MPOB germplasms. 


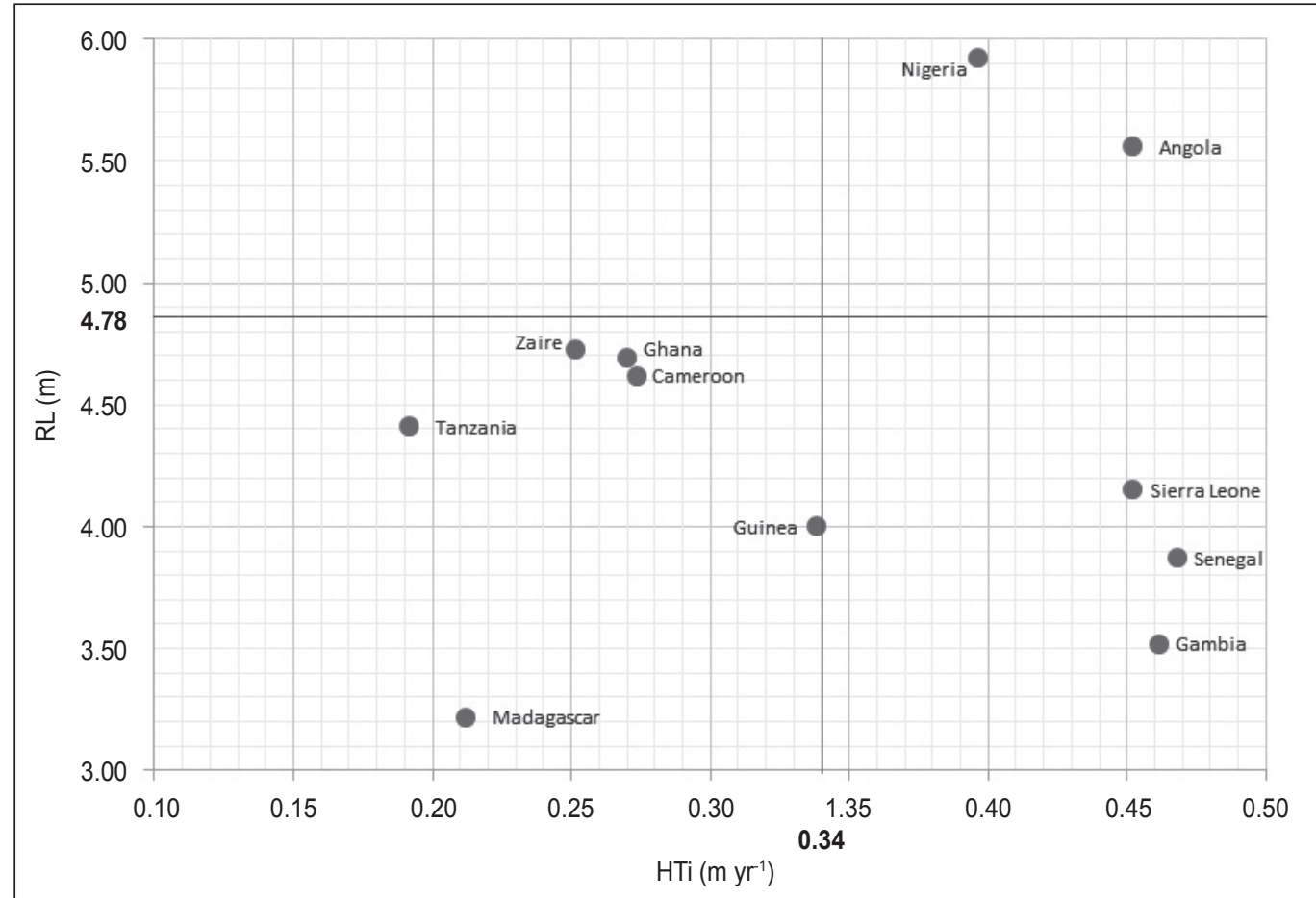

Note: (-) - grand mean.

RL - rachis length.

HTi - height increment.

Figure 3. Scatter plot of compact palms excluding duras with fresh fruit bunch yield of less than $100 \mathrm{~kg} \mathrm{palm}^{-1} \mathrm{yr}^{-1}$ in MPOB germplasm.

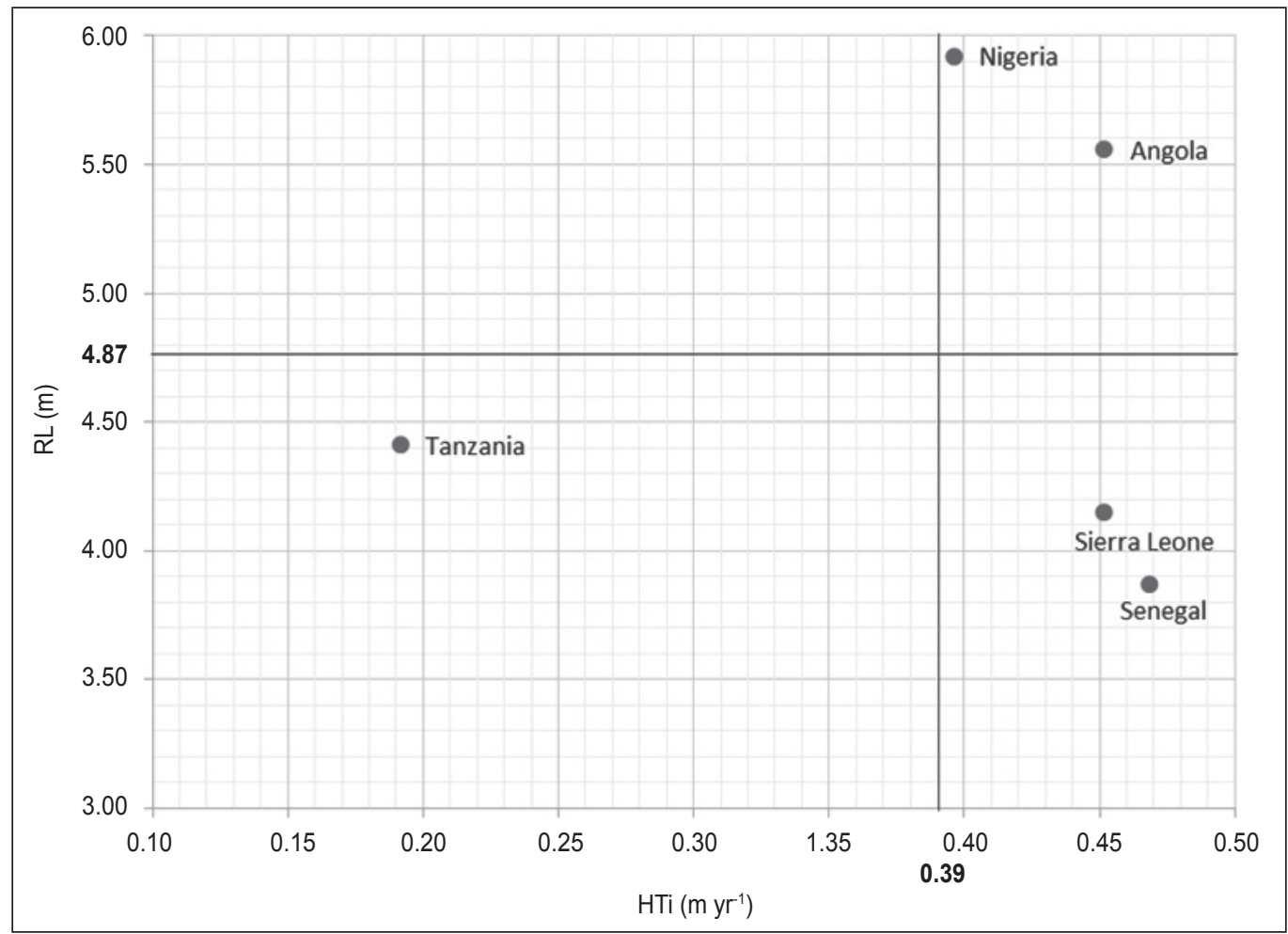

Note: (-) - grand mean.

RL - rachis length.

HTi - height increment.

Figure 4. Scatter plot of compact palms among duras in MPOB germplasm. 


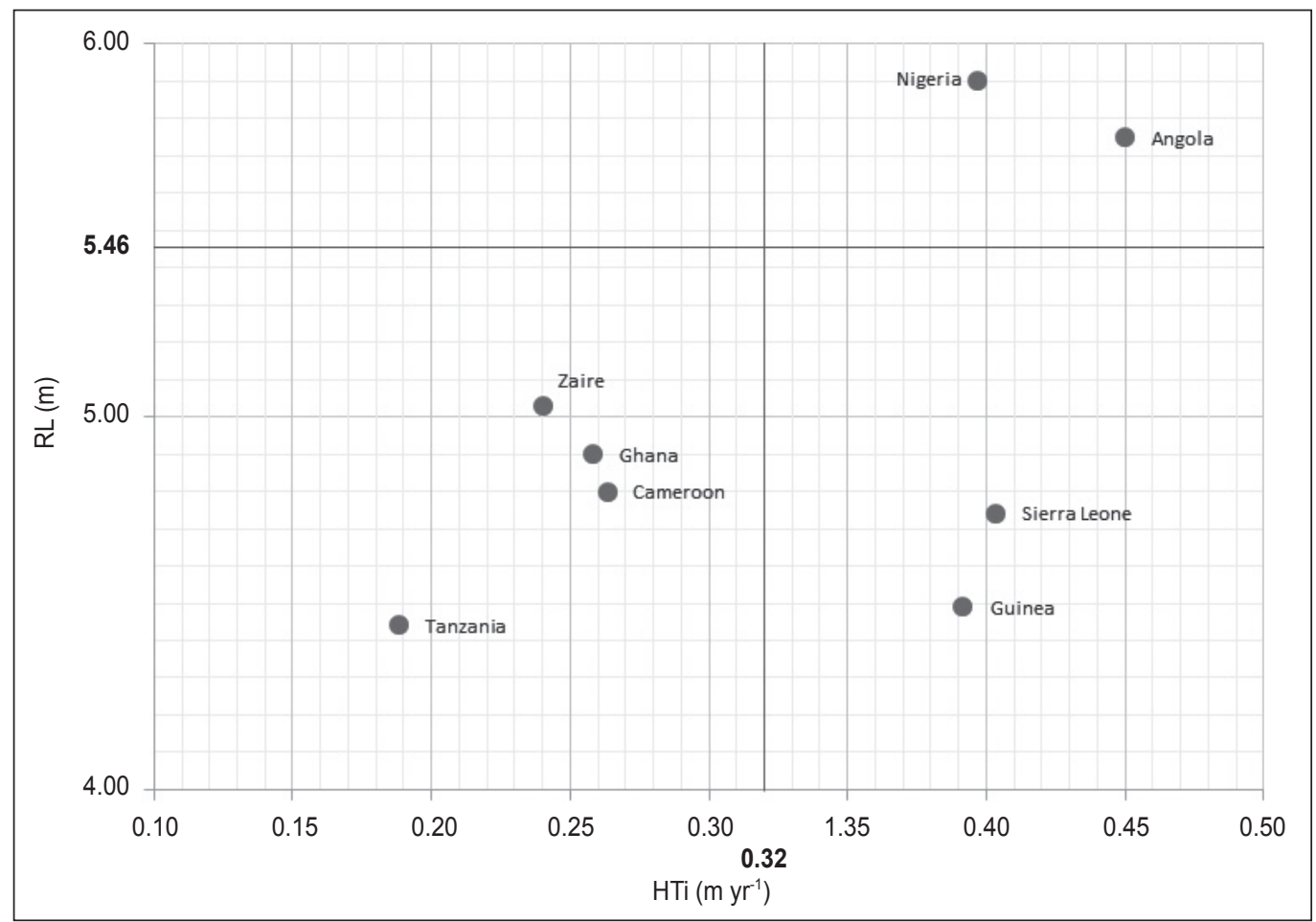

Note: (-) - grand mean. RL - rachis length. HTi - height increment.

Figure 5. Scatter plot of compact palms among teneras in MPOB germplasm.

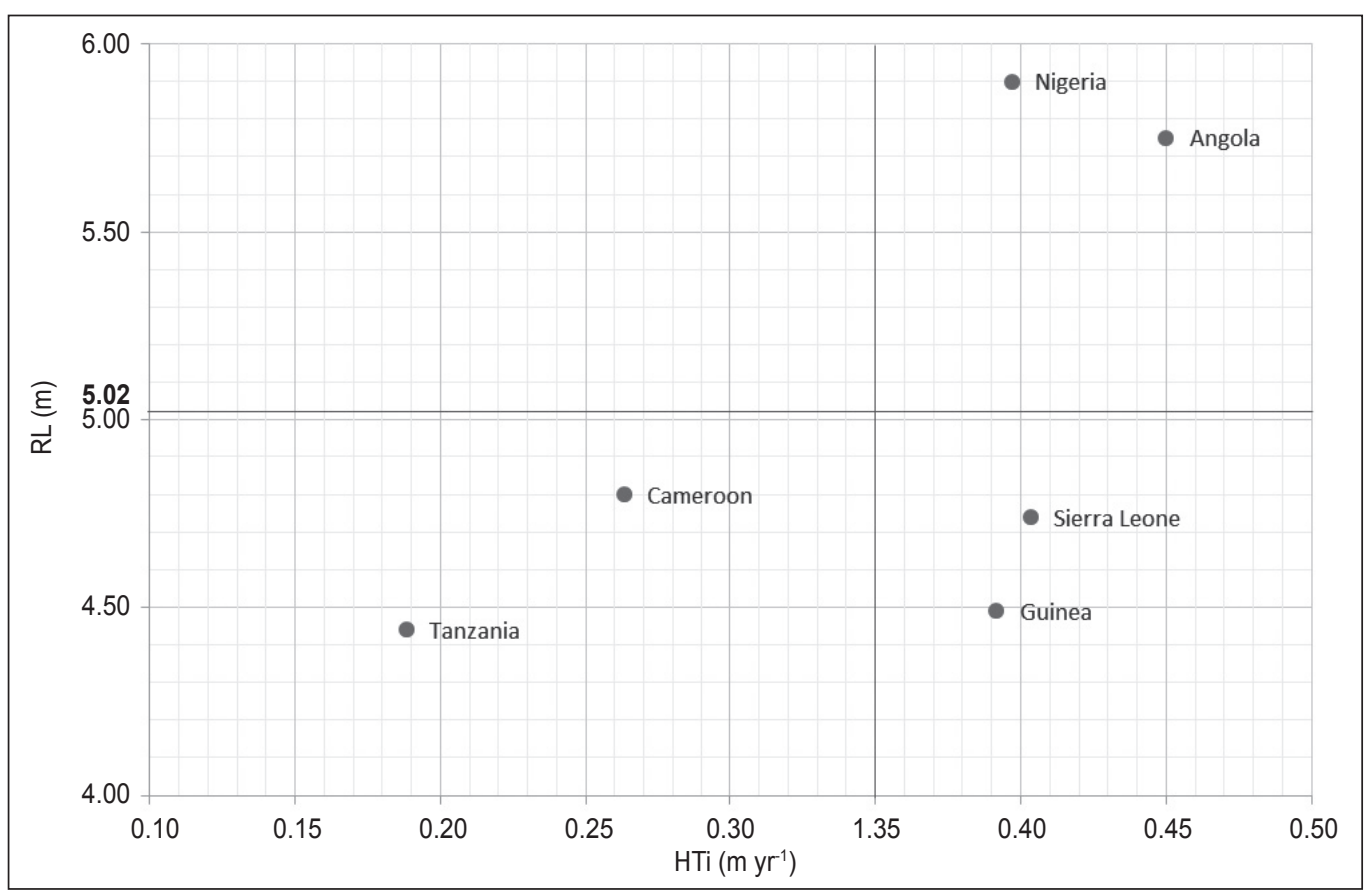

Note: (-) - grand mean. RL - rachis length. HTi - height increment.

Figure 6. Scatter plot of compact palms excluding teneras with fresh fruit bunch yield of less than $100 \mathrm{~kg} \mathrm{palm}^{-1} \mathrm{yr}^{-1}$ in MPOB germplasm.

RL of all germplasms was negatively correlated to frond production (FP) except for Madagascar which was positive and high $(>0.50)$ in duras. As for teneras, RL was found to be positively and significantly correlated with frond production in Nigeria. Correlation analysis also showed strong relationships for other pairs of traits. There was medium to high positive correlation between RL 
and petiole cross-section (PCS), leaflet length (LL), leaflet width (LW) and leaf number (LN). However, there was low to medium positive correlation between RL and palm height (HT) among the germplasms. Selection of one trait will bring along the effect of other traits. Therefore, selecting for low RL coincided with lower height increment. Isa et al. (2008) reported that the oil palms with lower HTi found in some Nigerian derived progenies are amenable to easier harvesting and mechanisation. The correlation between RL and trunk diameter (DIA) was low to medium amongst the germplasm in duras. It was also noted that there was no significant correlation between RL of most germplasms to DIA in teneras.

\section{CONCLUSION}

Based on the results from this study, the Tanzania germplasm showed good potential as breeding material for compactness with reasonable yield. It is envisaged that the introduction of these materials into commercial populations would improve planting materials in this country. Further efforts would be to introgress the short RL (less than $5 \mathrm{~m}$ ) and low HTi (less than $0.3 \mathrm{~m} \mathrm{yr}^{-1}$ ) palms into advanced breeding populations. Through the new combination, the best materials would be further evaluated and later exploited for future commercial seed production. It is recommended that progeny testing and evaluation of genotypeenvironment (GxE) interactions should be obtained before the germplasm can be used commercially.

\section{ACKNOWLEDGEMENT}

The authors would like to thank the Director-General of MPOB for permission to publish this article.

\section{REFERENCES}

Alvarado, A; Escobar, R and Peralta, F (2010). ASD's oil palm breeding program and its contributions to the oil palm industry. ASD Oil Palm Papers, 34: $1-16$.

Barcelos, E; De Almeida Rios, S; Cunha, R N V; Lopes, R; Motoike, S Y; Babiychuk, E; Skirycz, A and Kushnir, S (2015). Oil palm natural diversity and the potential for yield improvement. Front. Plant Sci., 6: 190.

Breure, C J and Corley, R H V (1983). Selection of oil palms for high density planting. Euphytica, 32: 177186.
Corley, R H V and Breure, C J (1981). Measurements in Oil Palm Experiments. Internal Report. Unipamol Malaysia and Harisons Fleming Advisory Services. $17 \mathrm{pp}$.

Corley, R H V and Tinker, P B (2003). The Oil Palm. Oxford: John Wiley and Sons. 562 pp.

Falconer, D S and Mackay, T F C (1996). Introduction to Quantitative Genetics. Fourth edition. Longmans Green, Harlow, Essex, UK. 464 pp.

Guzman, N and Peralta, F (2010). Advances in tissue culture propagation of compact oil palm clones in Costa Rica. Proc. of the Advances in Oil Palm Tissue Culture. Yogyakarta, Indonesia. p. 5966.

Isa, Z A; Mohd Din, A; Maizura, I; Noh A; Kushairi, A and Rajanaidu, N (2006). PS12: Breeding population for high oleic acid palm oil. MPOB Information Series No. 313: 2 pp.

Isa, Z A; Ong, K P; Norasyikin, I and Suboh, O (2008). Performance of MPOB-Nigerian population 12 - An update. Proc. of the $3^{\text {rd }}$ Seminar on Performance of MPOB PS1 and PS2 Materials and Elite Germplasm. MPOB, Bangi. p. 139-149.

Jusoh, L; Mohd Noor, M; Mohd Tayeb, D and Kushairi, A (2003). Economics of higher planting in oil palm plantations. Oil Palm Industry Economic J. Vol. 3(2): 32-39.

Kushairi, A; Rajanaidu, N and Jalani, B S (1999). PORIM Series 2. PORIM Information Series No. 101: $2 \mathrm{pp}$.

Kushairi, A; Rajanaidu, N; Mohd Din, A; Isa, Z A; Noh, A and Junaidah, J (2003). PS6: Breeding populations selected for large fruit duras. $M P O B$ Information Series No. 184: 2 pp.

Kushairi, A; Singh, R and Ong-Abdullah, M (2018). The oil palm industry in Malaysia: Thriving with transformative technologies. J. Oil Palm Res. Vol. 29 (2): 431-439.

Noh, A; Kushairi, A; Mohd Din, A; Maizura, I; Isa, ZA and Rajanaidu, N (2005). PS10: Breeding populations selected for long stalk. MPOB Information Series No. 263: 2 pp.

Noh, A; Rajanaidu, N; Kushairi, A; Mohd Rafii, Y; Mohd Din, A; Mohd Isa, Z A and Saleh, G (2002). Variability in fatty acid composition, iodine value and carotene content in the MPOB oil palm germplasm collection from Angola. J. Oil Palm Res. Vol. 14: 18-23. 
Okoye, M N; Okwuagwu, CO and Uguru, M I (2009). Population improvement for fresh fruit bunch yield and yield components in oil palm (Elaeis guineensis Jacq.). American-Eurasian J. Scientific Research, 4(2): 59-63.

Okoye, M N; Bakoume, C; Uguru, M I and Singh, R (2018). Genetic diversity and relatedness of oil palm progenies determined by microsatellite and agronomic markers. African J. Biotechnology, 17(18): 614-625.

Palat, T; Chayawat, N and Corley, R H V (2012). Maximising oil palm yield by high density planting and thinning. The Planter, 88: 241-256.

Phalan, B; Green, R E; Dicks, L V; Dotta, G; Feniuk, C; Lamb, A; Strassburg, B B N; Williams, D R; $\mathrm{Zu}$ Ermgassen, E K H J and Balmford, A (2016). How can higher-yield farming help to spare nature? Mechanisms to link yield increases with conservation. Science, 351(6272): 450-451.

Rajanaidu, N; Ainul, M M; Kushairi, A and Mohd Din, A (2013). Historical review of oil palm breeding for the past 50 years - Malaysian journey. Proc. of the International Seminar on Oil Palm Breeding - Yesterday, Today and Tomorrow. p. 11-28.

Rajanaidu, N (1986). The oil palm (Elaeis guineensis) collections in Africa. Proc. of the International
Workshop on Oil Palm Germplasm and Utilisation. PORIM, Bangi. p. 59-83.

Rajanaidu, N and Rao, V (1987). Oil palm genetic collections: Their performance and use to the industry. Proc. of the International Oil Conference in Agriculture. p. 59-85.

Rajanaidu, N; Kushairi, A; Rafii, M; Mohd Din, A; Maizura, I and Jalani, B S (2000). Oil palm breeding and genetic resources. Advances in Oil Palm Research (Yusof, B; Jalani, B S and Chan, K W eds.). Vol. 1. MPOB, Bangi. p. 171-237.

Samsul, K R; Zamzuri, I; Fadila, A M; Nor Azwani, A B; Naqiudin, M H; Dalilah, A B and Tarmizi, A H (2018). Clonal Palm Series 2 (CPS2). $M P O B$ Information Series No. 782: 2 pp.

Simmonds, N W (1986). Principles of Crop Improvement. Singapore: ELBS. 408 pp.

Woittiez, L S; Van Wijk, M T; Slingerland, M; Van Noorwijk, M and Giller, K E (2017). Yield gaps in oil palm: A quantitative review of contributing factors. Europ. J. Agronomy, 83: 57-77.

Zamzuri, I (2011). MPOB clonal propagation programme. Proc. of the International Seminar on Breeding for Sustainability in Oil Palm. MPOB, Bangi. p. 110-124. 